\title{
De invloed van werk en organisatie op innovatief werkgedrag
}

\author{
Frank Pot, Karolus Kraan en Seth van den Bossche*
}

\begin{abstract}
Innovatie is een belangrijk thema geworden in veel organisaties, van bedrijfsleven tot gezondheidszorg. Het meeste onderzoek naar welke factoren innovatie beïnvloeden gaat over markten, technologie en strategie. $\mathrm{Er}$ is nog weinig onderzoek gedaan naar het innovatief gedrag van medewerkers en de factoren die daarmee samenhangen. In een representatieve steekproef voor de Nederlandse beroepsbevolking is nagegaan in hoeverre werkkenmerken en een innovatief organisatieklimaat van invloed zijn op innovatief werkgedrag (bijdragen aan betere en/of nieuwe producten en/of diensten). De variantie in innovatief werkgedrag wordt vooral verklaard door een innovatief organisatieklimaat en het hebben van gevarieerd werk, in mindere mate door taakautonomie en het hebben van externe contacten. Sociale steun van leiding of collega's en tevredenheid met het HR-beleid lijken niet van invloed. Anders dan verwacht leiden kwantitatieve taakeisen niet tot minder innovatief werkgedrag, maar is er een zwak positief verband.
\end{abstract}

Trefwoorden: innovatief werkgedrag, innovatief organisatieklimaat, werkkenmerken

\section{Inleiding}

\section{Trends en debat}

Bij een vergrijzende en kleiner wordende beroepsbevolking is de ontwikkeling en de inzet van alle talenten noodzakelijk om ons niveau van welvaart en sociale zekerheid in stand te houden. Dat is ook nodig om de toenemende concurrentie door mondialisering te weerstaan en een sterke Nederlands-Europese kenniseconomie te creëren. Ontwikkeling van talent is onderdeel van wat tegenwoordig 'sociale innovatie' wordt genoemd, samen met vernieuwing van werkorganisatie en arbeidsverhoudingen (Pot et al., 2008; Pot \& Vaas, 2008). De sociale partners zijn het vergaand eens over een aantal hoofdlijnen van beleid: employability, leeftijdsfasebeleid, gezondheidsmanagement en flexibel organiseren.

De Sociaal-Economische Raad (SER), de Wetenschappelijke Raad voor het Regeringsbeleid (WRR), de ministeries van Economische en Sociale Zaken en het Innovatieplatform wijzen in recente documenten op de noodzaak van sociale innovatie. Sociale partners en kennisinstellingen hebben het Nederlands Centrum voor Sociale Innovatie opgericht. Kennisinstellingen hebben hun programma's op dit gebied ondergebracht in een topinstituut sociale innovatie (INSCOPE).

Dat is de context waarin vraagstukken van arbeidsproductiviteit en innovatie opnieuw op de agenda zijn gekomen. Dat was ook de aanleiding om daaraan ook in de Nationale Enquête Arbeidsomstandigheden (de NEA; de survey die we in dit onderzoek gebruiken) in 2007 aandacht te besteden. In dit artikel kijken we naar innovatief gedrag van werknemers.

* Frank Pot is verbonden aan de Radboud Universiteit Nijmegen, Institute for Management Research, Postbus 9108, 6500 HK Nijmegen. E-mail: f.pot@fm.ru.nl.

Karolus Kraan is werkzaam bij TNO Kwaliteit van Leven | Arbeid te Hoofddorp.

Seth van den Bossche is werkzaam bij TNO Kwaliteit van Leven | Arbeid te Hoofddorp. 
Er is een lange traditie van onderzoek naar factoren die innovativiteit van organisaties beïnvloeden. Meestal wordt dan gekeken naar omgevingsfactoren en kenmerken en uitkomsten op organisatieniveau. Daaruit komt bijvoorbeeld naar voren dat organisaties die hun medewerkers gevarieerd werk bieden en hen betrekken bij het oplossen van problemen, innovatiever zijn dan Tayloristische organisaties met veel monotone taken en weinig regelmogelijkheden (Arundel et al. 2006). Uit een ander onderzoek blijkt dat centrale besluitvorming een belemmering is voor radicale innovaties en dat formalisering van procedures en ook hechte sociale relaties in de eenheden bevorderlijk zijn voor 'incrementele innovatie', stapsgewijze verbetering van producten en processen (Jansen et al., 2006a). Dhondt en Vaas (1996) vonden eerder dat autonomie en volledigheid van functies bijdragen aan het innovatievermogen van organisaties.

Veel minder onderzoek is gedaan naar het innovatief gedrag van medewerkers als één van de determinanten van innovativiteit. In de hierboven geschetste context is de belangstelling daarvoor de laatste tien jaar groeiende. Welke factoren in de arbeid beïnvloeden innovatief werkgedrag? Als onderzoek antwoord kan geven op die vraag is wellicht verbetering van de condities mogelijk. Er lijkt ruimte te zijn voor versterking van het innovatieve werkgedrag van werknemers, zo is op te maken uit recent onderzoek van Huiskamp et al. (2008). In dat onderzoek naar 'goed werkgever- en werknemerschap' werd aan 450 leidinggevenden in de zorg, de industrie en de zakelijke dienstverlening gevraagd een oordeel te geven over het innovatieve gedrag van hun medewerkers. De leidinggevenden beoordeelden het innovatieve gedrag van hun werknemers gemiddeld iets voorbij het midden van een 5 -puntsschaal. Gemiddeld scoorden de werknemers iets hoger dan het neutrale 'enigszins', wat vrij vertaald neerkomt op een 'zesje' voor innovatief werkgedrag.

We zullen nu eerst bespreken wat we uit theorieën en uit eerder uitgevoerd onderzoek wijzer kunnen worden.

\section{Determinanten van innovatief werkgedrag}

Regelmogelijkheden (zoals taakautonomie) en sociale ondersteuning dragen bij aan het verkleinen van stressrisico's, het verruimen van leermogelijkheden en het verbeteren van prestaties, indien deze doelen bij het (her)ontwerpen van organisatie en functies bewust worden gecombineerd (Karasek \& Theorell, 1990). Karasek en Theorell onderscheiden in hun theoretische model drie dimensies: hoge of lage psychologische taakeisen, veel of weinig beslissingsruimte en veel of weinig sociale ondersteuning (van leidinggevende en/of collega's). De beslissingsruimte is een combinatie van taakautonomie en gevarieerd werk. ${ }^{1} \mathrm{Bij}$ lage taakeisen of weinig beslissingsruimte zijn de leermogelijkheden beperkt. Er is sprake van onderbenutting van competenties. De auteurs noemen dat 'verlies van innovatiepotentieel' (p. 199). Hoge taakeisen kunnen op zich al stimuleren tot slimmer werken om tijd te winnen en de belasting te beperken. De beste leermogelijkheden bestaan echter, wanneer het werk wordt gekenmerkt door een combinatie van hoge taakeisen en veel beslissingsruimte (active job, active learning-hypothese). Dit wordt nog versterkt wanneer er sprake is van veel sociale ondersteuning. Mensen voelen zich gemotiveerd om nieuwe gedragspatronen te ontwikkelen, die innovatie mogelijk bevorderen.

Een combinatie van hoge taakeisen en weinig beslissingsruimte is een stressrisico. Mensen worden immers niet overspannen van storingen of problemen op hun werk, maar van de onmogelijkheid om die op te lossen. Weinig sociale ondersteuning vergroot 
dat risico. Stress belemmert leren, zo stellen Karasek en Theorell bondig vast. Daarmee vormt stress dus ook een mogelijke belemmering voor innovatief gedrag.

In zijn theorie van de sociotechniek werkt De Sitter (1994) dat verder uit. Het gaat de integraal ontwerper van sociotechnische huize om zowel de kwaliteit van de arbeid als de kwaliteit van de organisatie. Beide doelen worden in het ontwerpproces doelbewust gecombineerd. 'Het benutten van menselijke vermogens is de kurk waarop een economie drijft' (p. 39). Dat benutten gebeurt het beste door actief werk te creëren. De Sitter volgt daarbij dezelfde redenering als Karasek en Theorell. Onder andere met het oog op de leermogelijkheden maakt hij een onderscheid tussen interne regelmogelijkheden en externe regelmogelijkheden. 'Intern' betreft het oplossen van storingen en problemen in het eigen werk. 'Extern' gaat over problemen die buiten het bereik van de eigen speelruimte liggen: de werkorganisatie, de productietechniek en de besturing, bijvoorbeeld in de vorm van werkoverleg. Interne en externe regelmogelijkheden bevorderen het leren. Vooral de externe regelmogelijkheden bevorderen bovendien de betrokkenheid bij de organisatie. Omgekeerd is bij een lage externe regelcapaciteit het vervreemdingsrisico - en dus het risico van onverschilligheid - hoog.

Vanuit de vraag hoe mensen op en van het werk leren, is in dezelfde gedachtegang (d.w.z. het belang van interne en externe regelmogelijkheden) en in positieve ontwerptermen door Hacker het concept 'volledige functie' ontwikkeld. Dat is een functie die hiërarchisch volledig (d.w.z. een combinatie van makkelijke en moeilijke taken), vaktechnisch volledig (voorbereidende, uitvoerende en ondersteunende taken) en organisatorisch of bestuurlijk volledig is (een samenhangend geheel van organiserende of coördinerende taken). Hoe vollediger een functie, hoe groter de kans op leren (Christis, 1998, p. 54-55).

Er is de laatste twintig jaar veel empirisch onderzoek uitgevoerd op basis van bovengenoemde theoretische modellen (Karasek, De Sitter, Hacker). Daarbij stond met name de relatie tussen werkkenmerken en de mentale gezondheid van werknemers centraal. Toch zijn ook diverse studies verschenen waarin aanknopingspunten te vinden zijn ten aanzien van de wijze waarop werkkenmerken, leren en innovatief gedrag samenhangen.

In de theoretische beschouwingen hebben we impliciet aangenomen dat leren op het werk zal leiden tot innovatief werkgedrag en tot betere resultaten van de organisatie. Wij zijn het met Taris (2007) eens die daarover in zijn oratie opmerkte dat die relatie nog nauwelijks is onderzocht. In het hier besproken onderzoek van anderen en in het hierna te rapporteren eigen onderzoek is daarmee in ieder geval een begin gemaakt.

\section{Taakautonomie en gevarieerd werk}

Taris en Kompier (2005) hebben achttien studies op het gebied van werkkenmerken en leren bekeken. In tien studies werd het veronderstelde verband tussen enerzijds taakeisen en regelmogelijkheden en anderzijds actief leren gevonden. In de overige gevallen was er wel een positief verband met regelmogelijkheden maar niet met taakeisen. Een beperking van deze conclusies is dat het meeste onderzoek cross-sectioneel is en er derhalve moeilijk uitspraken over causaliteit kunnen worden gedaan. Echter, in twee Nederlandse longitudinale onderzoeken - één onder werkende jongeren (Taris \& Feij, 2005) en één onder politieagenten (Taris et al., 2007) - bleek dat de combinatie van taakeisen en regelmogelijkheden inderdaad het leergedrag voorspelt. 
In het hierna te bespreken onderzoek naar innovatief werkgedrag is nog niet gekeken naar een gecombineerd effect van taakautonomie en taakeisen.

In een onderzoek van De Jong en Den Hartog (2005) onder kenniswerkers in het midden- en kleinbedrijf werd duidelijk dat er een direct effect is van taakautonomie en variatie in het werk op innovatief gedrag. In bedrijven met strategische aandacht voor innovatie gingen vooral medewerkers met gevarieerd werk en taakautonomie innovatief werkgedrag vertonen.

Molleman en Van den Beukel (2004) keken in een onderzoek naar de relatie tussen brede inzetbaarheid in zelfsturende teams en innovatieve werkprestaties. Anders dan de onderzoekers verwachtten, leidde brede inzetbaarheid, in het geval van veel autonomie en variatie, niet tot meer innovatieve werkprestaties dan beperkte inzetbaarheid. $\mathrm{Bij}$ geringe taakautonomie en monotone taken leidde brede inzetbaarheid zelfs tot minder innovatieve werkprestaties dan beperkte inzetbaarheid.

Het onderzoek van Dorenbosch, Van Engen en Verhagen bij een lokale overheidsorganisatie gaf een positieve samenhang te zien tussen multifunctionele functies (verschillende taken, een breed takenpakket) en innovatief werkgedrag. Deze samenhang werd versterkt door de mate waarin medewerkers zorg voor en eigenaarschap van de problemen op het werk voelden (Dorenbosch et al., 2005).

We concluderen dat er een direct effect lijkt te zijn van taakautonomie en van gevarieerd werk op innovatief werkgedrag. We concluderen ook dat taakautonomie in combinatie met taakeisen waarschijnlijk samenhangt met innovatief gedrag. Deze laatste conclusie is echter gebaseerd op het besproken onderzoek naar leren omdat het onderzoek naar innovatief werkgedrag niet over die combinatie ging.

\section{Taakeisen}

Ook de variabele kwantitatieve taakeisen (soms ook aangeduid met de begrippen werkdruk of roloverlading) blijkt verschillende effecten te kunnen hebben. Hogere taakeisen belemmeren innovatief werkgedrag als medewerkers de opbrengsten van hun inspanningen niet meer positief waarderen (Janssen, 2000; 2001). Zolang medewerkers wel opbrengsten zien van hun innovatief gedrag kan werkdruk dat zelfs bevorderen, evenwel tot een bepaalde grens (Janssen, 2001).

Het positieve verband tussen veel roloverlading (hoge taakeisen) en innovatief werkgedrag blijkt sterker bij medewerkers die rolambiguïteit ervaren. Rolambiguïteit betreft onduidelijkheden over de rolverwachtingen; onduidelijk is wat precies de vereisten en regelmogelijkheden van een rol zijn. Medewerkers benutten de speelruimte die rolambiguïteit geeft om het werk zo uit te voeren dat de als belastend ervaren roloverlading minder wordt. De prijs daarvoor blijkt stress te zijn. In het geval van beperkte roloverlading (lage taakeisen) verkleint rolambiguïteit de kans op innovatief werkgedrag omdat er geen noodzaak is om de ambigue regelmogelijkheden te benutten (De Jong \& Janssen, 2005). In hetzelfde onderzoek werd geen verband gevonden tussen roloverlading (taakeisen) en innovatief werkgedrag bij medewerkers die rolduidelijkheid ervaarden. Rolduidelijkheid op zichzelf gaat wel samen met een - beperkte - mate van innovatief werkgedrag.

Uit het onderzoek onder politieagenten (Taris et al., 2007) bleek dat de positieve relatie tussen taakeisen en regelmogelijkheden (taakautonomie) ook het zelfvertrouwen bevorderde en dat dit zelfvertrouwen ervoor zorgde dat de agenten op termijn minder 
stress gingen ervaren. Waar wel sprake was van stress, bleek dit samen te gaan met een mindere motivatie om te leren.

Uit de geciteerde review door Taris en Kompier (2005) blijkt dat in bijna de helft van de onderzoeken er geen sprake was van een direct verband tussen hoge taakeisen en leren. In de paragraaf over regelmogelijkheden is besproken dat in de andere onderzoeken een gecombineerd effect optrad van regelmogelijkheden en taakeisen.

In een onderzoek naar werken in virtuele teams bleek wel weer een positieve relatie tussen hoge taakeisen en innovatief gedrag (De Leede et al., 2008).

We concluderen dat het directe effect van taakeisen op leren en innovatief gedrag heel divers is en sterk door andere variabelen wordt beïnvloed. Het onderzoek tot nu toe levert geen consistente inzichten op. Het meest waarschijnlijke verband is dat bij hoge taakeisen stress optreedt waardoor leren en daarmee ook innovatief werkgedrag wordt bemoeilijkt.

\section{Sociale ondersteuning}

Innovatief gedrag wordt ook bevorderd door aanmoediging van leidinggevenden. Uit een onderzoek van Janssen (2005) komt naar voren dat medewerkers vaker innovatieve activiteiten ondernemen als zij waarnemen dat hun leidinggevende innovatieve acties van medewerkers ondersteunt.

De Jong en Den Hartog (2005) vonden geen verband tussen innovatief werkgedrag en de steun die een medewerker van collega's ervaart voor innovatieve activiteiten (zij noemen dat 'werkklimaat').

In zijn onderzoek onder kenniswerkers in commerciële bedrijven vindt De Jong (2007) dat leiderschap positief samenhangt met innovatief werkgedrag, overleggen en delegeren (participatief leiderschap), meer dan met visie presenteren, intellectueel stimuleren en innovatierolmodel zijn (transformationeel leiderschap).

We concluderen dat steun van de leidinggevende waarschijnlijk belangrijk is. Over de relatie van steun door collega's en innovatief gedrag hebben we niet meer recent onderzoek gevonden, maar toch nemen we aan dat ook dat belangrijk kan zijn.

Naast kenmerken van het werk zelf kunnen op basis van de literatuur nog enkele andere factoren geïdentificeerd worden die innovatief werkgedrag mogelijk bevorderen, te weten: het hebben van 'externe' contacten, de kwaliteit van het HR-beleid en innovatief organisatieklimaat.

\section{'Externe' contacten}

Het onderzoek van De Jong en Den Hartog (2005) en De Jong (2007) laat een direct verband zien tussen 'externe' contacten voor het werk en innovatief gedrag. Met externe contacten wordt hier bedoeld: contacten met klanten leveranciers, concurrenten en kennisinstellingen. Naar onze mening zou dit ook kunnen gelden voor contacten met collega's van andere afdelingen (vergelijk ook de opkomst van crossfunctionele, multidisciplinaire teams). Werknemers krijgen dan immers meer oog voor de context waarbinnen het eigen werk wordt uitgevoerd, en een beter zicht op eventuele verbeteren vernieuwingsmogelijkheden.

Ook in een review van De Waal $(2005 ; 2007)$ van onderzoeken naar factoren die bepalen of een organisatie een 'high performance organisation' is, komen dit soort contacten als 
belangrijk naar voren. De conditie 'externe contacten' werd - gebaseerd op verschillende innovatieonderzoeken - ook opgenomen in de Community Innovation Surveys (CIS) van Eurostat (2004).

Concluderend verwachten we dat contacten met collega's van andere afdelingen, met toeleveranciers en klanten kunnen stimuleren tot het verbeteren en vernieuwen van producten en diensten.

\section{Human resources management}

Het zou zo kunnen zijn dat kenmerken van de werkorganisatie weliswaar samenhangen met innovatief werkgedrag, maar dat de tevredenheid over het human resources-beleid (HR-beleid) daar ook mee samenhangt.

Dorenbosch et al. (2005) vonden dat medewerkers die 'high commitment HRM practices' rapporteerden in hun organisatie hoger scoorden op innovatief werkgedrag. Het ging dan bijvoorbeeld om HRM-praktijken ten aanzien van participatie, training en ontwikkeling, informatiedeling en steun door leidinggevende. Dit effect werd versterkt door de mate waarin medewerkers zorg voor en eigenaarschap van de problemen op hun werk ervaarden.

Een breed opgezet onderzoek in Canada geeft ook aanleiding om een relatie tussen HR-beleid en innovatief gedrag te vermoeden ook al is de uitkomstvariabele niet individueel gedrag maar innovatieprestaties van de organisatie. In dit onderzoek bleek dat 'HRM practices' een positieve en significante rol spelen bij de 'innovation performance', bijvoorbeeld: de voorspelde waarschijnlijkheid om een 'first-to-the-market' innovator te zijn is $35 \%$ voor organisaties die meer dan zes 'HRM practices' gebruiken, $11 \%$ bij drie of minder 'practices', en $4 \%$ als geen enkele 'HRM practice' wordt gebruikt. Naarmate de samenhang tussen 'HRM-practices' groter is, is de kans om 'first-to-the-market' innovator te zijn dus groter (Therrien \& Léonard, 2003).

We concluderen dat het zin heeft om na te gaan of tevredenheid met het HR-beleid samenhangt met innovatief werkgedrag en of deze gezamenlijk met de werkorganisatiekenmerken van invloed zijn op het innovatief werkgedrag.

\section{Innovatief organisatieklimaat}

Onder een innovatief organisatieklimaat kan veel verstaan worden. Het belang ervan wordt door veel onderzoekers onderstreept; er circuleren echter verschillende conceptualisaties en operationalisaties. Kauffeld et al. (2004) hebben zelfs een meetinstrument met 21 items ontwikkeld, de Fragebogen zum Innovationsklima (INNO). Bij de validering vond men vier factoren: activerend leiderschap, continue reflectie, consequente implementatie en professionele documentatie. Uitkomsten van onderzoek met de INNO zijn ons niet bekend. Het is de vraag of zo'n omvangrijke vragenlijst nodig is.

Ter onderscheiding van andere variabelen zouden wij onder innovatief organisatieklimaat vooral willen verstaan: stimulerend leiderschap, het beschikbaar stellen van middelen (tijd en geld) en het positief waarderen van ideeën voor verbetering en vernieuwing.

De Jong en Den Hartog (2005) vinden een positief verband tussen 'strategische aandacht voor innovatie' en innovatief gedrag. In zijn promotieonderzoek vindt De Jong (2007) geen verband tussen 'innovatieklimaat' (niet-bedreigende sfeer; streven naar excellentie; steun voor innovatie) en innovatief werkgedrag. De Leede et al. (2008) 
vinden dat innovatief gedrag van mensen in virtuele teams samenhangt met een wijze van interne controle die niet zozeer is gebaseerd op het afspreken van 'targets', maar op vertrouwen. Baer en Frese (2003) gebruiken het concept 'climate for initiative'. Zij noemen topmanagement support als het belangrijkste voor het creëren van een algemeen 'climate for initiative', maar in hun meting van het concept wordt niet direct gevraagd naar de rol van de leidinggevende. Van de Voorde et al. (submitted) vonden in hun onderzoek in verschillende organisaties dat een 'empowered workplace' positief samenhangt met innovatief werkgedrag. In het begrip 'empowered workplace' zijn besloten: charismatisch leiderschap, leermogelijkheden, onafhankelijkheid in het werk, participatie en gevarieerd werk.

We concluderen dat een stimulerend klimaat voor innovatie van belang kan zijn voor innovatief werkgedrag. Mogelijk versterkt een innovatief klimaat andere verbanden tussen werkkenmerken en innovatief gedrag omdat het directer op dat gedrag gericht is.

Samenvattend is er in het onderzoek veel ondersteuning voor de aanname dat gevarieerd werk en taakautonomie samengaan met innovatief werkgedrag. Maar soms zijn er verrassende uitzonderingen, bijvoorbeeld in het geval van brede inzetbaarheid (Molleman \& Van den Breukel, 2004). De invloed van taakeisen is verschillend en kennelijk afhankelijk van andere condities. Naar de invloed van sociale ondersteuning, externe contacten, HR-beleid en innovatief klimaat op innovatief gedrag is nog weinig onderzoek gedaan. Voeg hierbij de maatschappelijke relevantie en er is genoeg reden om de volgende onderzoeksvragen en hypothesen te formuleren.

\section{Onderzoeksvragen}

De centrale vraag van deze studie is:

In welke mate beïnvloeden kenmerken van de werkorganisatie en andere elementen van het organisatiebeleid innovatief werkgedrag?

Innovatief werkgedrag is in dit onderzoek gericht op productinnovatie, namelijk de bijdrage die een medewerker levert aan het verbeteren van bestaande producten en diensten en aan het bedenken van nieuwe producten en diensten. Bijdragen aan bijvoorbeeld procesoptimalisatie kunnen natuurlijk ook worden aangemerkt als innovatief werkgedrag. In de NEA is alleen gevraagd of de leidinggevende dat stimuleert (een item van 'innovatief organisatieklimaat', een conditie), niet of de respondent aan procesoptimalisatie bijdraagt (als een item van 'innovatief werkgedrag', de uitkomstmaat).

Op grond van de hierboven behandelde theorieën en onderzoeksresultaten verwachten we dat innovatief werkgedrag bevorderd zal worden door taakautonomie, gevarieerd werk, externe contacten en steun van leidinggevende en collega's. Volgens dezelfde theorieën zouden hoge kwantitatieve taakeisen de leermogelijkheden kunnen beperken. Zoals eerder aangegeven, is apart bevraagd of de organisatie innovatief werkgedrag stimuleert door hiervoor ruimte te creëren en medewerkers aan te moedigen tot innovatie. Dat zou ook innovatief gedrag kunnen bevorderen. We noemen dat innovatief organisatieklimaat. Voorts vragen we ons af wat het effect van tevredenheid met het HR-beleid op innovatief werkgedrag kan zijn. Naast deze 'hoofdeffecten' zijn we ten slotte geïnteresseerd in de vragen hoe regelmogelijkheden gezamenlijk met taakeisen innovatief werkgedrag beïnvloeden (interactie-effecten) en hoe deze en andere ken- 
merken van de werkorganisatie en HR-beleid enerzijds en het innovatieve organisatieklimaat anderzijds gezamenlijk het innovatieve werkgedrag beïnvloeden (interactieeffecten).

\section{Hypothesen}

\section{Hoofdeffecten:}

1 Medewerkers vertonen meer innovatief werkgedrag naarmate zij (a) meer gevarieerd werk hebben, (b) over meer taakautonomie beschikken, (c) meer sociale steun van hun leidinggevende krijgen, (d) meer sociale steun van hun collega's krijgen, en/of (e) meer externe contacten hebben in hun werk.

2 Naarmate medewerkers hogere kwantitatieve taakeisen ervaren, vertonen zij minder innovatief werkgedrag.

3 Naarmate medewerkers tevredener zijn over het HR-beleid, vertonen zij meer innovatief werkgedrag.

4 Waar een innovatiever organisatieklimaat heerst, vertonen medewerkers meer innovatief werkgedrag.

Interactie-effecten:

5 Hogere taakeisen zijn gunstig voor innovatief werkgedrag als gevarieerd werk, taakautonomie, sociale steun leidinggevende en/of sociale steun collega's in sterkere mate aanwezig zijn.

6 Hogere scores op de werkkenmerken (a) gevarieerd werk, (b) taakautonomie, (c) sociale steun leidinggevende, (d) sociale steun collega's, en (e) externe contacten en (f) tevredenheid HR-beleid, zijn vooral gunstig voor innovatief werkgedrag als in sterkere mate sprake is van een innovatief organisatieklimaat.

Figuur I Conceptueel model: kenmerken van werkorganisatie, organisatiebeleid en innovatief werkgedrag (hoofd- en interactie-effecten)

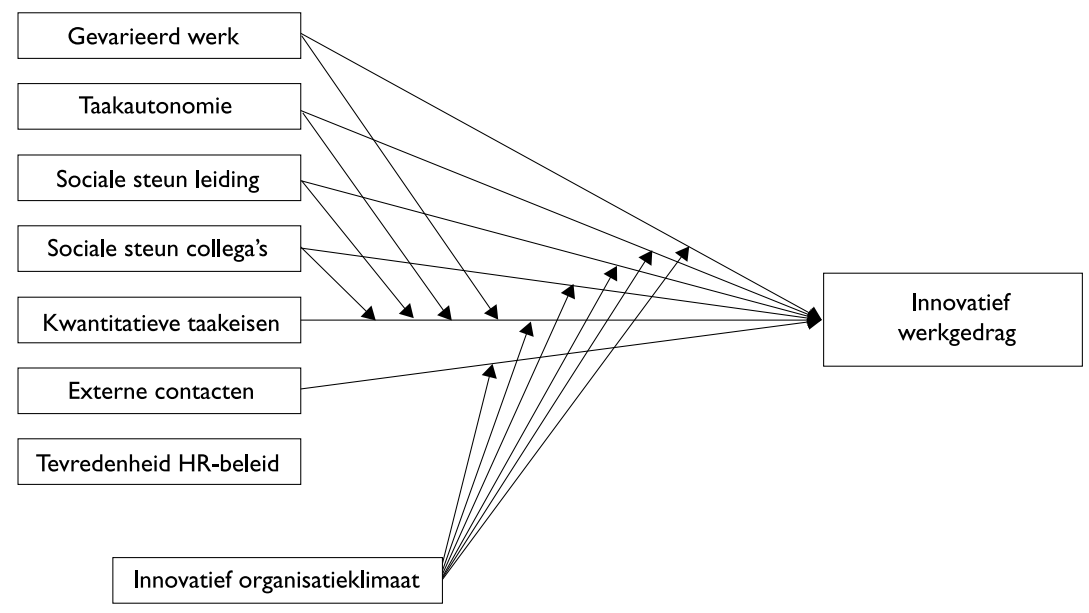




\section{Methode}

\section{Data}

Om bovenstaande onderzoeksvragen te beantwoorden zijn analyses uitgevoerd op de Nationale Enquête Arbeidsomstandigheden (NEA) 2007. De Nationale Enquête Arbeidsomstandigheden (NEA) is een grootschalig periodiek onderzoek naar de arbeidssituatie van werknemers in Nederland. De versie 2007 is de vierde meting. De steekproef is getrokken uit het zogenoemde banenbestand van het CBS. In 2007 werd de NEA ingevuld door 22.759 werknemers van 15 tot 65 jaar (32,8\% respons). Deze respons is gangbaar bij dit type steekproefonderzoek. De enquête kan zowel schriftelijk als via internet worden ingevuld. Circa $80 \%$ van de respondenten verkoos de schriftelijke variant en $20 \%$ de webversie. Omdat bij de steekproeftrekking het risico op selectiviteit vanwege non-respons niet volledig valt uit te sluiten, is in de NEA weging toegepast. Deze weging vond plaats op basis van geslacht, leeftijd, herkomst, bedrijfstak, regio, stedelijkheid en opleidingsniveau. De NEA-steekproef vormt een representatieve afspiegeling van het werkzame deel van de Nederlandse beroepsbevolking, exclusief zelfstandigen. Voor een uitgebreide bespreking van de inhoud en de kwaliteit van de NEA verwijzen we naar Van den Bossche et al. (2008).

\section{Onderzoeksvariabelen}

Omdat de NEA als doel heeft om over een breed scala van onderwerpen informatie voor monitoring te genereren, wordt in een aantal gevallen gebruik gemaakt van verkorte versies van bestaande schalen.

De onafhankelijke variabele 'Gevarieerd werk' is gemeten met drie vragen die, vertaald, gebaseerd zijn op de skill discretion-schaal uit de Job Content Questionnaire (JCQ) (Karasek, 1985; Karasek et al., 1998).

'Taakautonomie' is eveneens gemeten met drie vragen, gebaseerd op de JCQ. Het verwijst naar de mate waarin een werknemer in staat is zijn eigen werk te reguleren. Het gaat dan zowel om de keuzevrijheid ten aanzien van de manier van werken, als de planning en volgorde van werkzaamheden.

'Sociale steun leidinggevende' en 'Sociale steun collega's' zijn beide met vier vragen gemeten uit de JCQ.

'Externe contacten' is gebaseerd op de antwoorden op een drietal vragen naar contacten met collega's buiten het eigen team/afdeling/vestiging, klanten en toeleveranciers/ onderaannemers. Deze vragen zijn door TNO opgesteld. Naar contacten met kennisinstellingen is in de NEA helaas niet gevraagd.

'Kwantitatieve taakeisen' is gemeten met vier vragen, die afkomstig zijn uit de JCQ. Het concept verwijst naar de hoeveelheid werk en tijdsdruk waaronder werkzaamheden verricht dienen te worden.

Voor 'Tevredenheid met HR-beleid' is een schaal geconstrueerd op basis van antwoorden over tevredenheid met een viertal HR-aspecten, te weten: salaris, functioneringsgesprekken, promotie- en loopbaanmogelijkheden, scholings- en opleidingsmogelijkheden (rapportcijfer 1-10). De vragen zijn afgeleid van de Monitor Arbeidsvoorwaarden en arbeidsverhoudingen op ondernemingsniveau (AVON; Ten Have et al., 2007).

'Innovatief organisatieklimaat' is samengesteld uit de antwoorden op twee vragen: 'Op mijn werk worden werknemers aangemoedigd om na te denken over manieren om hun werk beter te doen' (ontleend aan de QPS Nordic; Lindström et al., 1997), en 'In mijn 
werk krijg ik tijd om nieuwe ideeën te ontwikkelen', gebaseerd op de vragenlijst van het PASO-werkgeverspanel (Panel Survey of Organisations; Universiteit Gent, KU Leuven \& de Vlerick Leuven Gent Management School, 2004).

De afhankelijke variabele 'Innovatief werkgedrag' is gemeten met twee items: 'In mijn werk lever ik een duidelijke bijdrage aan het bedenken van nieuwe producten/diensten van mijn bedrijf' en 'In mijn werk lever ik een duidelijke bijdrage aan het verbeteren van producten/diensten van mijn bedrijf. Beide vragen zijn een bewerking van items uit de Erasmus Concurrentie- en Innovatiemonitor voor werkgevers (Jansen et al., 2006b).

Alle schalen zijn minimaal voldoende betrouwbaar gemeten. Dat is met uitzondering van het concept 'externe' contacten. Dat dit geen schaal vormt, maar eerder een index, is niet verwonderlijk omdat het om uiteenlopende externe contacten gaat. In tabel 1 staan voorbeelditems en betrouwbaarheden van de gemeten concepten weergegeven.

\section{Tabel I Concepten, met voorbeelditems en betrouwbaarheden (Cronbachs $\alpha$ )}

\begin{tabular}{|c|c|c|c|}
\hline Concept & Voorbeelditems (met antwoordcategorieën) & $\begin{array}{l}\text { Aantal } \\
\text { items }\end{array}$ & $\alpha$ \\
\hline Gevarieerd werk & $\begin{array}{l}\text { Is uw werk gevarieerd? } \\
\text { Vereist uw baan dat u nieuwe dingen leert? } \\
(I=\text { nooit, } 4=\text { altijd })\end{array}$ & 3 &, 75 \\
\hline Taakautonomie & $\begin{array}{l}\text { Kunt u zelf beslissen hoe u uw werk uitvoert? } \\
\text { Kunt u zelf uw werktempo regelen? } \\
(\mathrm{I}=\text { nee, } 3=\mathrm{ja} \text {, meestal) }\end{array}$ & 3 & ,8I \\
\hline Sociale steun leiding & $\begin{array}{l}\text { Mijn leidinggevende heeft oog voor het welzijn van de } \\
\text { medewerkers } \\
\text { Mijn leidinggevende kan mensen goed laten samen- } \\
\text { werken } \\
\text { (I = helemaal mee oneens, } 4 \text { = helemaal mee eens) }\end{array}$ & 4 &, 88 \\
\hline Sociale steun collega's & $\begin{array}{l}\text { Mijn collega's helpen om het werk gedaan te krijgen } \\
\text { Mijn collega's zijn vriendelijk } \\
\text { (I = helemaal mee oneens, } 4=\text { helemaal mee eens })\end{array}$ & 4 &, 83 \\
\hline Externe contacten & $\begin{array}{l}\text { Hoe vaak heeft u bij het uitvoeren van uw functie } \\
\text { contact met de volgende personen en bedrijven? } \\
\text { Collega's van andere teams, afdelingen of vestigingen; } \\
\text { Klanten (of patiënten, leerlingen of passagiers, e.d.); } \\
\text { Toeleveranciers, onderaannemers } \\
\text { (I = nooit, } 5 \text { = dagelijks) }\end{array}$ & 3 & $(, 4 I)^{*}$ \\
\hline Kwantitatieve taakeisen & $\begin{array}{l}\text { Moet u erg snel werken? } \\
\text { Is uw werk 'hectisch'? } \\
(I=\text { nooit, } 4=\text { altijd })\end{array}$ & 4 & ,85 \\
\hline Tevredenheid HR-beleid & $\begin{array}{l}\text { Kunt u met een rapportcijfer aangeven hoe tevreden } \\
\text { u bent over de volgende zaken? } \\
\text { Salaris; Functioneringsgesprekken; Loopbaanmogelijk- } \\
\text { heden; Scholings- en opleidingsmogelijkheden } \\
\text { (I = zeer ontevreden, I0 = zeer tevreden) }\end{array}$ & 4 &, 80 \\
\hline Innovatief organisatieklimaat & $\begin{array}{l}\text { Op mijn werk worden werknemers aangemoedigd om } \\
\text { na te denken over manieren om het werk beter te } \\
\text { doen } \\
\text { In mijn werk krijg ik tijd om nieuwe ideeën te ontwik- } \\
\text { kelen } \\
(I=\text { nooit, } 4=\text { altijd })\end{array}$ & 2 & ,70 \\
\hline Innovatief werkgedrag & $\begin{array}{l}\text { In mijn werk lever ik een duidelijke bijdrage aan het } \\
\text { bedenken van nieuwe producten/diensten van mijn } \\
\text { bedrijf } \\
\text { In mijn werk lever ik een duidelijke bijdrage aan het } \\
\text { verbeteren van producten/diensten van mijn bedrijf } \\
(I=\text { nooit, } 4=\text { altijd })\end{array}$ & 2 & ,86 \\
\hline
\end{tabular}

\footnotetext{
* Betrouwbaarheid (interne consistentie) van deze schaal is te laag; constructscore berekend als gemiddelde
} over de items. 


\section{Uitgevoerde analyses}

Allereerst is op basis van univariate analyse (Pearson-correlaties) nagegaan of er achtergrondvariabelen zijn, waarvoor mogelijk gecorrigeerd dient te worden vanwege hun samenhang met innovatief werkgedrag. Onderzochte en in de analyses meegenomen variabelen zijn: sekse, wel of niet een leidinggevende functie, anciënniteit (aantal jaren in dienst bij de werkgever), opleiding en sector (twaalf klassen). De variabele leeftijd is buiten beschouwing gelaten vanwege de zeer sterke correlatie met anciënniteit en problemen van collineariteit die dat met zich meebrengt in multipele regressie-analyses; we achten het verband tussen anciënniteit en innovatief werkgedrag het meest relevant voor beleidsmakers in organisaties en kiezen daarom voor deze variabele boven leeftijd. Van de univariate correlaties met de uitkomstmaat innovatief werkgedrag bespreken we de correlaties kleiner dan -0,20 en groter dan 0,20. Bij de bespreking van de resultaten van de uitgevoerde multiple lineaire regressie-analyses op innovatief werkgedrag beschouwen we de effectgrootten (beta's) vanaf (-)0,10 of hoger als relevant. Immers, door het grote aantal respondenten in de dataset, zegt significantie alléén niet veel meer. Alle correlaties en regressiecoëfficiënten in de gepresenteerde tabellen zijn significant op $\mathrm{p}<0,001$-niveau, tenzij anders aangegeven.

Bij de regressie-analyses onderzoeken we ook de interactie-effecten. De verschillende blokken variabelen voeren we in de volgende volgorde in de analyse in (enter procedure): (1) de persoons- en organisatie-achtergrondkenmerken, (2) de kenmerken van de werkorganisatie en 'tevredenheid HR-beleid', (3) 'innovatief organisatieklimaat', (4) de interactietermen. ${ }^{2}$

\section{Resultaten}

De frequentieverdeling van de scores op de items die de variabele innovatief werkgedrag vormen, laat een voor het onderzoek interessante spreiding zien. Datzelfde geldt voor de, zoals zal blijken, belangrijkste voorspellende variabele: innovatief organisatieklimaat.

Tabel 2 Frequentieverdeling van de twee items innovatief werkgedrag (in \% van totaal)

\begin{tabular}{lcc}
\hline & $\begin{array}{c}\text { In mijn werk lever ik een duidelijke } \\
\text { bijdrage aan het bedenken van nieuwe } \\
\text { producten/diensten van mijn bedrijf }\end{array}$ & $\begin{array}{c}\text { In mijn werk lever ik een duidelijke } \\
\text { bijdrage aan het verbeteren van } \\
\text { producten/diensten van mijn bedrijf }\end{array}$ \\
\hline Nooit & 31,5 & 22,2 \\
Soms & 43,0 & 44,3 \\
Vaak & 19,4 & 25,8 \\
Altijd & 6,1 & 7,7 \\
Totaal & 100,0 & 100,0 \\
\hline
\end{tabular}

Tabel 3 Frequentieverdeling van de twee items innovatief organisatieklimaat (in \% van totaal)

\begin{tabular}{lcc}
\hline & $\begin{array}{c}\text { Op mijn werk worden werknemers } \\
\text { aangemoedigd om na te denken over } \\
\text { manieren om het werk beter te doen }\end{array}$ & $\begin{array}{c}\text { In mijn werk krijg ik tijd om nieuwe } \\
\text { ideeën te ontwikkelen }\end{array}$ \\
\hline Nooit & 10,8 & 18,5 \\
Soms & 38,2 & 46,4 \\
Vaak & 37,2 & 25,7 \\
Altijd & 13,8 & 9,5 \\
Totaal & 100,0 & 100,0 \\
\hline
\end{tabular}


Tussen de 26 en 34\% van de werknemers in Nederland rapporteert veel innovatief werkgedrag ('vaak' of 'altijd'), een kleine $45 \%$ zegt dat zij soms innovatief werkgedrag tonen. De helft van de respondenten ervaart dat medewerkers vaak of altijd worden aangemoedigd om na te denken over manieren om het werk beter te doen, de ander helft ervaart dat soms of nooit. Tijd om nieuwe ideeën te ontwikkelen krijgt $35 \%$ vaak of altijd, en $65 \%$ soms of nooit.

Uit de univariate analyses blijkt dat de achtergrondkenmerken leidinggeven $(r=, 31)$ en opleidingsniveau $(r=, 29)$ sterk samenhangen met innovatief gedrag. Leidinggevenden lijken dus meer innovatief werkgedrag te vertonen dan niet-leidinggevenden, terwijl hoger opgeleiden meer innovatief werkgedrag vertonen dan lager opgeleiden.

Voor de centrale variabelen van deze studie laat de univariate analyse verder zien dat de volgende variabelen een (redelijk) sterke samenhang hebben met innovatief werkgedrag: innovatief organisatieklimaat $(r=, 60)$, gevarieerd werk $(r=, 48)$, taakautonomie $(r=, 28)$, tevredenheid HR-beleid $(r=, 25)$, externe contacten $(r=, 23)$ en sociale steun leidinggevende $(r=, 21)$.

Tabel 4 Beschrijvende statistieken en correlaties voor de centrale variabelen

\begin{tabular}{|c|c|c|c|c|c|c|c|c|c|c|c|c|c|}
\hline & & $\mathbf{N}$ & Gem. & SD & I & 2 & 3 & 4 & 5 & 6 & 7 & 8 & 9 \\
\hline I. & $\begin{array}{l}\text { Gevarieerd werk } \\
(I=\text { nooit, } 4=\text { altijd })\end{array}$ & 22.558 & 2,72 & 69 & I & & & & & & & & \\
\hline 2. & $\begin{array}{l}\text { Taakautonomie } \\
(I=\text { nee, } 3=\text { ja, meestal })\end{array}$ & 22.477 & 2,53 & ,49 & ,22 & 1 & & & & & & & \\
\hline 3. & $\begin{array}{l}\text { Sociale steun leiding } \\
(I=\text { helemaal mee oneens, } \\
4=\text { helemaal mee eens })\end{array}$ & 21.415 & 2,84 & ,67 & ,20 &, 14 & 1 & & & & & & \\
\hline 4. & $\begin{array}{l}\text { Sociale steun collega's } \\
\text { ( } 1=\text { helemaal mee oneens, } \\
4=\text { helemaal mee eens })\end{array}$ & 21.838 & 3,24 &, 50 &, 19 & ,05 & ,34 & 1 & & & & & \\
\hline 5. & $\begin{array}{l}\text { Externe contacten } \\
(\mid=\text { nooit, } 5=\text { dagelijks })\end{array}$ & 22.363 & 3,52 & ,98 &, 23 &, 13 & ,06 & ,09 & 1 & & & & \\
\hline 6. & $\begin{array}{l}\text { Kwantitatieve taakeisen } \\
(1=\text { nooit, } 4=\text { altijd })\end{array}$ & 22.518 & 2,32 & ,62 & ,20 &,- 05 &,- 17 &,- 04 &, 16 & 1 & & & \\
\hline 7. & $\begin{array}{l}\text { Tevredenheid HR-beleid } \\
(I=\text { zeer ontevreden, } 10=\text { zeer } \\
\text { tevreden })\end{array}$ & 19.439 & 6,01 & $\mathrm{I}, 74$ &, 26 & ,21 & ,48 & ,23 & ,09 &,- 11 & I & & \\
\hline 8. & $\begin{array}{l}\text { Innovatief organisatieklimaat } \\
(I=\text { nooit, } 4=\text { altijd })\end{array}$ & 22.372 & 2,40 & ,76 & ,48 &, 25 & ,38 &, 21 &, 18 & ,07 & ,40 & 1 & \\
\hline 9. & $\begin{array}{l}\text { Innovatief werkgedrag } \\
(I=\text { nooit, } 4=\text { altijd })\end{array}$ & 22.297 & 2,10 & ,81 & ,48 & ,28 & ,21 &, 13 & ,23 &, 19 & ,25 & ,60 & I \\
\hline
\end{tabular}

In de multipele regressie-analyse (tabel 5, met in model 1 de achtergrondkenmerken, respectievelijk aangevuld met kenmerken van de werkorganisatie in model 2, innovatief klimaat in model 3 en de interacties in model 4) zien we dat gevarieerd werk, taakautonomie en sociale steun van de leiding positief gerelateerd zijn aan innovatief werkgedrag van werknemers (model 2). De effecten van externe contacten en tevredenheid met HR-beleid zijn, in tegenstelling tot de univariate analyses, te verwaarlozen wanneer we corrigeren voor achtergrondkenmerken. We zien ten slotte dat de eerder geconstateerde samenhang tussen opleidingsniveau en leidinggeven enerzijds en innovatief gedrag anderzijds grotendeels gemedieerd lijkt te worden door de belangrijkste voorspellende werkkenmerken, gevarieerd werk en autonomie.

Bij de toevoeging van innovatief organisatieklimaat in model 3 zien we een sterk effect van innovatief organisatieklimaat $(\beta=, 44)$ op innovatief werkgedrag. Het effect van gevarieerd werk $(\Omega=, 17)$ uit model 2 , blijft in model 3 overeind, zij het in afgezwakte 
vorm (tabel 5). De effecten van taakautonomie en sociale steun van de leiding worden in model 3 echter voor een belangrijk deel, respectievelijk volledig 'wegverklaard'. De overige factoren veranderen niet of nauwelijks.

De variabelen zijn - ook zonder de bijdrage van innovatief organisatieklimaat - wel in staat een aanzienlijk deel van de variantie in innovatief werkgedrag te verklaren. Die is voor alle variabelen uit het onderzoeksmodel samen $45 \%$ (tabel 5, model 3). Zonder de variabele innovatief organisatieklimaat is de verklaarde variantie nog altijd $32 \%$ (tabel 5, model 2), wat relatief veel is voor sociaalwetenschappelijk onderzoek.

Bij de analyse van interacties die in de onderzoeksvragen zijn genoemd, zijn ten slotte geen effecten van enige betekenis gevonden (tabel 5, model 4), dus ook geen gecombineerde effecten van gevarieerd werk, taakautonomie, sociale steun leidinggevende of sociale steun collega's en kwantitatieve taakeisen.

\section{Conclusie en discussie}

We kunnen concluderen dat onze hypothesen slechts in beperkte mate worden bevestigd. Feitelijk vinden we alleen bewijs voor hypothese 1a (hoofdeffect van gevarieerd werk) en 4 (innovatief organisatieklimaat), de overige worden dus verworpen. De overige effecten verlopen grotendeels in de verwachte richting, met uitzondering van taakeisen, maar de effectgrootte is zeer gering (tabel 6). Kennelijk zijn autonomie in het werk, taakeisen, externe contacten, sociale steun en het HR-beleid dus minder van belang bij het stimuleren van innovatief gedrag, wanneer eenmaal sprake is van een 'innovatief organisatieklimaat'.

Opvallend is dat de sociale steun van collega's geen rol speelt en dat het belang van sociale steun van de leidinggevende in de analyses wordt wegverklaard door innovatief organisatieklimaat. De rol van de leidinggevende komt natuurlijk wel deels aan de orde als onderdeel van het innovatieve organisatieklimaat. Het effect van innovatief organisatieklimaat ('Aanmoediging tot nadenken over manieren het werk beter te doen'; 'tijd krijgen') is deels op te vatten als een specificatie van de bredere concepten steun van de leiding en van taakautonomie.

Het verwachte negatieve verband met kwantitatieve taakeisen blijkt juist een - zeer zwak - positief verband te zijn. Mensen die het druk hebben, zijn misschien soms ook de mensen die tijd besteden aan innovatie van producten en diensten. Dat kan een zodanige voldoening opleveren dat geen stress optreedt. Dit zou dus overeenkomen met de interpretatie van Janssen (2000; 2001): Zolang mensen de opbrengsten van hoge taakeisen positief waarderen, vormen die geen belemmering. Indien nieuw onderzoek ook in die richting zou wijzen, moet de theorie 'hoge taakeisen leiden tot stress en stress belemmert leren' worden genuanceerd. We zijn overigens nagegaan of het verband tussen taakeisen en innovatief gedrag mogelijk kromlijnig is, maar dat bleek niet het geval.

Dat taakautonomie maar een zeer zwak verband laat zien, is verrassend, omdat in veel van het besproken onderzoek taakautonomie wel een rol blijkt te spelen. De variabele innovatief organisatieklimaat is dominant. Die ontbrak in dat andere onderzoek. Gegeven het sterke verband tussen innovatief organisatieklimaat en innovatief werkgedrag (in het als laatste getoetste model) en omdat de vragen van beide schalen in elkaars verlengde liggen, moeten we zoals gezegd evenwel rekening houden met een eventuele common method bias. 
Tabel 5 Resultaten van lineaire regressie-analyses met innovatief werkgedrag als afhankelijke variabele

\begin{tabular}{|c|c|c|c|c|c|c|c|c|}
\hline \multirow[b]{2}{*}{ Onafhankelijke variabelen } & \multicolumn{2}{|c|}{ Model I } & \multicolumn{2}{|c|}{ Model 2} & \multicolumn{2}{|c|}{ Model 3} & \multicolumn{2}{|c|}{ Model 4} \\
\hline & $\mathbf{B}$ & $\mathbf{p}$ & $\mathbf{B}$ & $\mathbf{p}$ & B & $\mathbf{p}$ & B & $\mathbf{p}$ \\
\hline \multicolumn{9}{|l|}{ Blok I: Achtergrondkenmerken } \\
\hline Geslacht $(I=\operatorname{man} ; 2=$ vrouw $)$ &,- 09 & $* * *$ &,- 07 & $* * *$ &,- 07 & $* * *$ &,- 07 & $* * *$ \\
\hline \multicolumn{9}{|l|}{ Opleiding (< = VBO = referentie) } \\
\hline midden (HAVO-MBO) &, 12 & $* * *$ & ,06 & $* * *$ & 05 & $* * *$ & 05 & $* * *$ \\
\hline hoger (HBO-WO) & ,30 & $* * *$ &, 17 & $* * *$ &, 15 & $* * *$ &, 15 & $* * *$ \\
\hline Anciënniteit & ,01 & & ,01 & $*$ & ,0l & & 02 & $* *$ \\
\hline Leidinggevende functie $(\mathrm{I}=\mathrm{ja}, 0=$ nee $)$ &, 24 & $* * *$ &, 13 & $* * *$ & , II & $* * *$ & , II & $* * *$ \\
\hline \multicolumn{9}{|l|}{ Sector (Industrie $=$ referentie) } \\
\hline landbouw en visserij &,- 03 & $* * *$ &,- 01 & &,- 01 & &,- 01 & \\
\hline bouwnijverheid &,- 05 & $* * *$ &,- 06 & **** &,- 05 & $* * *$ &,- 05 & $* * *$ \\
\hline handel &,- 04 & $* * *$ &,- 02 & $* *$ &,- 01 & &,- 01 & \\
\hline horeca &,- 00 & &, 02 & $*$ &, 01 & $*$ &, 02 & $* *$ \\
\hline vervoer en communicatie &,- 06 & $* * *$ &,- 03 & $* * *$ &,- 02 & ** &,- 02 & $* *$ \\
\hline financiële dienstverlening &,- 01 & &,- 03 & $* * *$ &,- 04 & $* * *$ &,- 04 & $* * *$ \\
\hline zakelijke dienstverlening &,- 01 & &,- 02 & &,- 02 & $* *$ &,- 02 & $* *$ \\
\hline openbaar bestuur &,- 02 & ** &,- 03 & $* * *$ &,- 02 & $*$ &,- 01 & \\
\hline gezondheids- en welzijnszorg &,- 01 & &,- 02 & $*$ &,- 01 & &,- 01 & \\
\hline cultuur en overige dienstverlening &, 01 & &, 01 & & ,0l & &, 01 & \\
\hline \multicolumn{9}{|l|}{ Blok 2: Werkorganisatie en HRM-beleid } \\
\hline Gevarieerd werk & & & ,30 & **** &, 17 & $* * *$ &, 17 & $* * *$ \\
\hline Taakautonomie & & &, 12 & $* * *$ & ,09 & $* * *$ & ,09 & $* * *$ \\
\hline Steun leiding & & & , II & $* * *$ & ,01 & &, 01 & \\
\hline Steun collega's & & & ,01 & &,- 01 & &,- 01 & $*$ \\
\hline Externe contacten & & & ,08 & $* * *$ & ,07 & $* * *$ &, 07 & $* * *$ \\
\hline Kwantitatieve taakeisen & & & ,09 & **** & 08 & $* * *$ &, 07 & $* * *$ \\
\hline Tevredenheid HR-beleid & & &, 07 & **** &,- 01 & $*$ &,- 01 & \\
\hline \multicolumn{9}{|l|}{ Blok 3: Innovatief organisatieklimaat } \\
\hline Innovatief organisatieklimaat & & & & & ,44 & $* * *$ & ,43 & $* * *$ \\
\hline \multicolumn{9}{|l|}{ Blok 4: Interactietermen } \\
\hline Taakautonomie $\times$ Taakeisen & & & & & & &, 02 & $* *$ \\
\hline Steun leiding $\times$ Taakeisen & & & & & & &,- 02 & $*$ \\
\hline Steun collega's $\times$ Taakeisen & & & & & & &, 01 & \\
\hline Gevarieerd werk $\times$ Innovatief klimaat & & & & & & &, 04 & $* * *$ \\
\hline Taakautonomie $\times$ Innovatief klimaat & & & & & & &, 02 & $* *$ \\
\hline Steun leiding $\times$ Innovatief klimaat & & & & & & & ,03 & $* *$ \\
\hline Steun collega's $\times$ Innovatief klimaat & & & & & & &,- 01 & $*$ \\
\hline Externe contacten $\times$ Innovatief klimaat & & & & & & & ,02 & $* * *$ \\
\hline Kwant. taakeisen $\times$ Innovatief klimaat & & & & & & &,- 00 & \\
\hline Tevredenheid HR-beleid $\times$ Innovatief klimaat & & & & & & &, 01 & \\
\hline R2 (Adjusted R2) &, 15 & $(, 15)$ &, 32 & $(, 32)$ & ,45 ( & $(, 45)$ & ,45 & $(, 45)$ \\
\hline$F(p)$ & 196 & $(* * *)$ & 369 & $(* * *)$ & 598 & $(* * *)$ & 425 & $(* * *)$ \\
\hline R2 Change & , I & 5 & & 18 & , I & 2 & & .01 \\
\hline F Change (p) & - & - & 630 & $(* * *)$ & 3817 & $(* * *)$ & 15 & $(* * *)$ \\
\hline
\end{tabular}

De verschillende blokken werden stepwise met enter-procedure ingevoerd; $N=16.999 ; * p<, 05 ; * * p<, 01$; $* * * *$ p $<, 000$. 
Tabel 6 Overzicht van de verbanden met 'innovatief werkgedrag'

\begin{tabular}{lr}
\hline Gevarieerd werk & + \\
Taakautonomie & + \\
Sociale steun leiding & 0 \\
Sociale steun collega's & 0 \\
Externe contacten & + \\
Kwantitatieve taakeisen & - \\
Tevredenheid HR-beleid & 0 \\
Innovatief organisatieklimaat & ++ \\
Interacties & 0
\end{tabular}

++ = sterk verband, in positieve richting; + = zwak verband positief; 0 = geen verband; - = zwak verband negatief; effecten gecorrigeerd voor achtergrondkenmerken en voor elkaar

In de inleiding hebben we besproken dat de 'active job active learning hypothese' (hoge taakeisen en veel beslissingsruimte) niet vanzelfsprekend hoeft op te gaan voor innovatief gedrag. In dit onderzoek is in ieder geval geen bevestiging gevonden voor de 'active job active innovation hypothese'.

Natuurlijk is één onderzoek te weinig om vast te stellen dat de combinatie van taakautonomie en taakeisen geen rol zou spelen bij innovatief gedrag. Maar dit onderzoek en de eerder besproken onderzoeken geven aanleiding om ook het effect van taakeisen op zichzelf beter te onderzoeken. Onder welke condities bevorderen of belemmeren taakeisen innovatief gedrag? Deze vraag is des te meer van belang nu, in het tijdperk van de kenniseconomie, kenniswerkers in toenemende mate met hoge taakeisen te maken hebben, mede doordat werk en privé meer door elkaar gaan lopen, terwijl van hen toch innovatief gedrag wordt verwacht.

Er is een meer omvattende theorie over condities voor innovatief gedrag nodig, waarvoor dit artikel bouwstenen levert, met innovatief klimaat, gevarieerd werk, autonomie en taakeisen als belangrijke concepten. We zijn het eens met Rietzschel en Janssen (2008) die onder andere pleiten voor het onderzoeken van de verbinding tussen creativiteit en innovatie en voor meer onderzoek naar 'variabelen op het individuele niveau die bepalen of het individu zowel in staat (cognitieve bekwaamheden, persoonlijkheid) als bereid (motieven, attitudes, doelen) is om creatieve en innovatieve inspanningen te plegen' (p. 83-84). Taris (2007, p. 15) pleit voor meer onderzoek naar de theoretisch veronderstelde samenhangen tussen enerzijds werkkenmerken en anderzijds psychologische constructen als motivatie ('willen'), cognitie ('denken') en gedrag ('doen').

Een andere, complementaire richting van onderzoek die we bepleiten is die van de regelmogelijkheden. In het onderzoek tot nu toe gaat het vooral over het begrip autonomie dat is geoperationaliseerd met vragen over interne regelmogelijkheden. Op theoretische gronden kunnen we evenwel verwachten dat externe regelmogelijkheden een grote bijdrage leveren aan leren en juist aan innoveren omdat werkorganisatie, productietechniek en besturing ter discussie komen. Double loop learning wordt mogelijk. Of, zoals De Sitter (1994, p. 359) zegt: 'Innoveren staat dus gelijk aan non-routine regelen.' Aanknopingspunten biedt ook de theorie van Sabel (2006) over de innovative organization. Dit type organisatie lost het probleem van de bounded rationality niet op door hiërarchie en routines zoals de klassieke organisatie doet, maar door netwerken en het permanent ter discussie stellen van routines.

Het huidige onderzoek heeft als sterkste kenmerken de grootte van de steekproef, de deelname van alle sectoren en beroepsgroepen en de mogelijkheid van periodieke 
herhaling. Het kent echter ook enkele beperkingen. Uiteraard geldt ook hier de aanbeveling voor longitudinale data, want zoals bij het meeste onderzoek zijn ook in deze studie cross-sectionele verbanden onderzocht - wat geen uitspraken over causaliteit toelaat. Een andere methodologische beperking is dat respondenten hun eigen innovatieve werkgedrag beoordeelden. In de opzet van de NEA 2007 kon dat niet anders, maar het zou interessant zijn als ook het oordeel daarover van de direct leidinggevende kon worden betrokken zoals De Jong (2007) heeft gedaan en zoals dat in toenemende mate gebeurt bij het onderzoek naar werkprestaties en productiviteit.

Een deel van de NEA 2008 heeft een longitudinaal karakter en is een vervolgmeting op de NEA 2007. Met een dergelijke longitudinale studie is naast het vaststellen van causaliteit, correctie mogelijk voor de zelfrapportagescores van de 2007-meting, eventuele zelfrapportage-effecten en common method bias wat bij veel onderzoek kan spelen. Met zo'n opzet kunnen de genoemde beperkingen gedeeltelijk worden ondervangen.

Inhoudelijk is het verder aanbevelenswaardig om in de volgende NEA het concept innovatief werkgedrag uit te breiden naar procesinnovatie of 'slimmer werken'. De huidige vragen betroffen innovatie van producten en diensten. Verder is het interessant het concept externe contacten meer te richten op samenwerking met kennisleveranciers.

Innovatief gedrag en productief gedrag zijn onderzoeksthema's, die een tijdlang minder belangrijk zijn geweest, maar de laatste jaren opnieuw in de belangstelling zijn gekomen. Dat hangt samen met maatschappelijke ontwikkelingen (mondiale concurrentie, ontgroening en vergrijzing beroepsbevolking) en politieke doelen (innovatie, verhogen arbeidsproductiviteit). Het onderzoek naar innovatief gedrag heeft nog maar weinig focus. De uitkomsten zijn daardoor lastig met elkaar te vergelijken. Een voorbeeld daarvan is dat in ons onderzoek 'innovatief organisatieklimaat' belangrijk blijkt en 'sociale steun leidinggevende' niet, terwijl in het onderzoek van De Jong (2007) 'innovatieklimaat' geen relatie heeft met innovatief werkgedrag, en 'leiderschap' wel. De operationalisaties van ogenschijnlijk dezelfde begrippen zijn zo verschillend dat de uitkomsten onvergelijkbaar zijn. Zowel theoretisch als empirisch is er nog werk te doen. In het voorgaande is uitbreiding van sommige schalen bepleit en toevoeging van nieuwe variabelen. De mogelijkheden daartoe zijn in het geval van een breed georiënteerd monitorinstrument als de NEA echter beperkt. Er zou veel gewonnen kunnen worden als er door meerdere onderzoekers van verschillende disciplines en verschillende onderzoeksinstellingen in verschillende landen programmatisch wordt samengewerkt. ${ }^{3}$ Het onderzoeken van concurrerende hypothesen kan daar uiteraard deel van uitmaken.

De percentages medewerkers die innovatief werkgedrag vertonen en de mate waarin het organisatieklimaat innovatief is, zijn lastig te beoordelen. Zijn ze hoog, zijn ze laag; gaat het om 'halfvolle of halflege glazen'? Waar moeten en kunnen ze mee vergeleken worden? De huidige cijfers lijken nog genoeg ruimte voor verbetering te laten zien. Volgende NEA-metingen zullen in ieder geval vergelijkingsmateriaal opleveren en uitwijzen in hoeverre innovatief werkgedrag onderhevig is aan verandering.

Voor zover het mogelijk is nu al adviezen voor de praktijk te geven, kan op basis van dit onderzoek worden gezegd, dat het stimuleren van innovatief gedrag, het tijd geven om nieuwe ideeën te ontwikkelen en het creëren van functies met gevarieerd werk een bijdrage leveren aan het innovatief gedrag van medewerkers. Of, in algemenere termen gesteld: inspirerend leiderschap en een werkorganisatie die talentontwikkeling en betrokkenheid bevordert. Niets nieuws dus, maar een bevestiging dat deze algemene condities ook van belang zijn voor innovatief werkgedrag. De beweging van sociale 
innovatie waarover we in het begin van dit artikel schreven heeft dit goed opgepakt. Praktijkervaring en nader onderzoek zullen duidelijk maken wat in het bijzonder, en in detail, de drivers zijn.

\section{Noten}

1 In het onderzoek van de laatste twintig jaar worden taakautonomie en gevarieerd werk niet gecombineerd tot één concept regelmogelijkheden, maar als aparte concepten beschouwd. Wij doen dat hier ook.

2 De interactietermen zijn de producten van de hoofdtermen werkorganisatie, HR-beleid en innovatief klimaat. Om collineariteit te voorkomen, zijn deze hoofdtermen, voor de berekening van het product, gecentreerd op de schaalgemiddelden (Aiken \& West, 1991).

3 Voor onderzoek naar innovatie op organisatie-, sector- en nationaal niveau is dat deels al gebeurd met de uitgebrachte Oslo Manual en de hierop gebaseerde Community Innovation Surveys van Eurostat.

\section{Literatuur}

Aiken, L.S. \& West, S.G. (1991). Multiple regression: Testing and interpreting interactions. Newbury Park, CA: SAGE.

Arundel, A., Lorentz, E., Lundvall, B-A. \& Valeyre, A. (2006). The organization of work and innovative performance: a comparison of the EU-15. Aalborg: Danish Research Unit for Industrial Dynamics.

Baer, M. \& Frese, M. (2003). Innovation is not enough: climates for initiative and psychological safety, process innovations, and firm performance. Journal of Organizational Behavior, 24, 45-68.

Bossche, S.N.J.van den, Koppes, L.L.J., Granzier, J.J.M., Vroome, E.M.M. de \& Smulders, P.G.W. (2008). Nationale Enquête Arbeidsomstandigheden 2007: Methodologie en globale resultaten. Hoofddorp: TNO.

Christis, J. (1998). Arbeid, organisatie en stress. Een visie vanuit de sociotechnische arbeids- en organisatiekunde. Amsterdam: Het Spinhuis.

Dhondt, S. \& Vaas, S. (1996). Innovatie en arbeid. Een onderzoek naar de synergie tussen kwaliteit van de arbeid en het innovatievermogen van bedrijven. Den Haag: VUGA.

Dorenbosch, L.W., Engen, M.L. van \& Verhagen, M. (2005). On-the-job Innovation: The Impact of Job Design and Human Resource Management through Production Ownership. Creativity and Innovation Management, 14(2), 129-141.

Eurostat \& National Statistical Offices (2004), The Fourth Community Innovation Survey. Vragenlijst. Luxemburg: Luxemburg.

Have, C.J.M. ten, Oeij, P.R.A. \& Kraan, K.O. (2007). Arbeidsvoorwaarden en arbeidsverhoudingen op ondernemingsniveau AVON Monitor 2007. Nr. 392. Den Haag: Ministerie van Sociale Zaken en Werkgelegenheid.

Huiskamp, R., Kraan, K. \& Sloten, G. van (2008). 'Wie goed doet, goed ontmoet': goed werkgeverschap voorspeller van goed werknemerschap? Tijdschrift voor Arbeidsvraagstukken, 24, 68-84.

Jansen, J.J.P., Bosch, F.A.J. van den \& Volberda, H.W. (2006a). Exploratory innovation, exploitative innovation, and performance. Effects of organizational antecedents and environmental moderators. Management Science, 52, 1661-1674.

Jansen, J.J.P., Bosch, F.A.J. van den \& Volberda, H.W. (2006b). Erasmus Concurrentie- en InnovatieMonitor. Vragenlijst. Rotterdam: Erasmus Universiteit/Rotterdam School of Management (RSM).

Janssen, O. (2000). Job demands, perceptions of effort-reward fairness, and innovative work behavior. Journal of occupational and Organizational Psychology, 73, 287-302.

Janssen, O. (2001). Fairness perceptions as a moderator in the curvilinear relationships between job demands, and job performance and job satisfaction. Academy of Management Journal, 44, 1039-1050. 
Janssen, O. (2005). The joint impact of perceived influence and supervisor supportiveness on employee innovative behaviour. Journal of Occupational and Organizational Psychology, 78, 573-579.

Jong, J.P.J. de \& Hartog, D.N. (2005). Determinanten van innovatief gedrag: een onderzoek onder kenniswerkers in het MKB. Gedrag \& Organisatie, 18, 235-259.

Jong, J.P.J. (2007). Individual innovation: the connection between leadership and employees' innovative work behavior. Zoetermeer, EIM (proefschrift UvA).

Jong, S.B. de \& Janssen, O. (2005). Innovatief werkgedrag en stress als reacties op roloverlading en rolambiguïteit. Gedrag \& Organisatie, 18, 66-82.

Karasek, R.A. (1985). Job content questionnaire and user's guide. Lowell: University of Massachusetts.

Karasek, R., Brisson, Ch., Kawakami, N., Houtman, I.L.D., Bongers, P. \& Amick, B. (1998). The Job Content Questionnaire (JCQ): an instrument for inter-nationally Comparative Assessments of Psychosocial Job Characteristics. Journal of Occupational Health Psychology, 3, 322355.

Karasek, R.A. \& Theorell, T. (1990). Healthy work; stress, productivity and the reconstruction of working life. New York: Basic Books.

Kauffeld, S., Jonas, E., Grote, S., Frey, D. \& Frieling, E. (2004). Innovationsklima - Konstruktion und erste psychometrische Überprüfung eines Messinstrumentes. Diagnostica, 50(3), 153164.

Leede, J. de, Kraan, K.O., Hengst, M. den \& Hooff, M.L.M. van (2008). Conditions for innovation behaviour of virtual team members: a 'high-road' for internationally dispersed virtual teams. The Journal of E-working, 2, 22-46.

Lindström, K., Dallner, M., Elo, A.L., Gamberale, F., Knardahl, S., Skogstad, A. \& Orhade, E. (1997). Review of Psychological and social factors at work and suggestions for the General Nordic questionnaire (QPS Nordic). Copenhagen: Nordic Council of Ministers.

Molleman, E. \& Beukel, A. van den (2004). Brede inzetbaarheid en haar gepercipieerde bijdrage aan team performance; de modererende rol van taakkenmerken. Gedrag \& Organisatie, 17, 472-486.

Nielsen, P. \& Danmarks Statistik (2001). DISKO (Danish Innovation System - Comparative Analysis) Management Questionnaire about organisation, employee skills and development of new products. Kopenhagen: Danmarks Statistik.

Pot, F., Peltzer, F. \& Xavier, M. (2008). Sociale innovatie en de rol van sociale partners. In S. Dhondt \& F. Vaas (red.), Waardevol werk; Van arbeidskwaliteit naar sociale innovatie (pp. 1938). Den Haag: Uitgeverij LEMMA.

Pot, F. \& Vaas, F. (2008). Social innovation: the Dutch experience. Personalführung, 7, 40-46.

Rietzschel, E. \& Janssen, O. (2008). Een overzicht van het sociaal- en organisatiepsychologisch onderzoek in Nederland naar creativiteit en innovatie. Gedrag \& Organisatie, 21, 74-87.

Sabel, C.F. (2006). A real-time revolution in routines. In C. Heckscher \& P. Adler (eds.), The firm as a collaborative community (pp. 106-156). Oxford University Press.

Sitter, L.U. de (1994). Synergetisch produceren. Human Resources Mobilisation in de produktie: een inleiding in de structuurbouw. Assen: Van Gorcum.

Taris, T.W. (2007). Al doende leert men. Oratie. Nijmegen: Radboud Universiteit.

Taris, T.W. \& Feij, J.A. (2005) Learning and strain among newcomers: a three-wave study on the effects of job demands and job control. Journal of Psychology, 138, 543-563.

Taris, T.W. \& Kompier, M.A.J. (2005). Job characteristics and learning behavior. In P.L. Perrewé \& D.C. Ganster (red.), Research in occupational stress and well-being: exploring interpersonal dynamic (vol. 4, pp. 127-166). Amsterdam: JAI Press.

Taris, T.W., Kompier, M.A.J., Geurts, S.A.E., Houtman, I.L.D. \& Heuvel, F. van den (2007). Job characteristics, strain, and learning among Dutch police officers: a longitudinal test of the learningrelated predictions of the demand-control model. Nijmegen/Hoofddorp: Radboud Universiteit/ TNO.

Therrien, P. \& Léonard, A. (2003). Empowering employees: A route to innovation. Ottawa: Ministry of Industry.

UGent, KULeuven \& de Vlerick Leuven Gent Management School (2002, 2003, 2004). Panel Survey of Organisations Flanders - PASO-vragenlijsten. Leuven/Gent: Steunpunt Ondernemerschap, Ondernemingen en Innovatie.

Voorde, K. van de, Dorenbosch, L.W. \& Kroon, B. (submitted). A multi-level examination of workplace-level empowerment and individual-level self-efficacy and personality on innovative work behaviour. 
Waal, A. de (2005). The Foundations of Nirvana; the Characteristics of a High Performance Organization. White Paper, MBA thesis. Leiden: Hyperion. (Retrieved on March 24th 2008 from www.management-development.com/uploads/455/255/HYPERION_whitepaper.pdf )

Waal, A. de (2007). The characteristics of a high performance organization. Business Strategy Series, 8, 179-185. 